\title{
PENGEMBANGAN SISTEM PENDUKUNG KEPUTUSAN PENENTUAN HOTEL DI KECAMATAN BULELENG DENGAN METODE ANALYTIC HIERARCHY PROCESS (AHP) DAN TECHNIQUE FOR OTHERS REFERENCE BY SIMILARITY TO IDEAL SOLUTION (TOPSIS)
}

\author{
I Nengah Agus Arimbawa Dwijayadi ${ }^{1}$, \\ I Made Agus Wirawan ${ }^{2}$, Dewa Gede Hendra Divayana ${ }^{3}$ \\ 1,2,3 Jurusan Pendidikan Teknik Informatika \\ Universitas Pendidikan Ganesha \\ Singaraja, Bali \\ e-mail: arim5293@gmail.com¹, imade.aguswirawan@undiksha.ac.id², \\ divayana182@gmail.com ${ }^{3}$
}

\begin{abstract}
Abstrak
Sistem pendukung keputusan penentuan hotel di Kecamatan Buleleng dengan metode AHP dan TOPSIS adalah sebuah sistem yang dikembangkan untuk membantu pengunjung dalam menentukan hotel yang dipilih sesuai dengan kriterianya. Metode penelitian yang digunakan dalam penelitian dan pengembangan sistem pendukung keputusan penentuan hotel ini dirancang dan dikembangkan sesuai tahap pada metode SDLC dengan model waterfall. Hasil penelitian ini adalah aplikasi website yang diimplementasikan dengan menggunakan Sublime Text 2 dengan Bahasa pemrograman PHP, HTML dan Javascrpit. Berdasarkan hasil pengujian dari sistem pendukung keputusan penentuan hotel di Kecamatan Buleleng dengan metode AHP dan TOPSIS menunjukkan, aplikasi tersebut sudah berjalan dengan sangat baik. Respon pengguna terhadap sistem pendukung keputusan penentuan hotel masuk dalam rentangan sangat baik dengan nilai persentasi $89 \%$.. Fitur yang disediakan dalam aplikasi antara lain informasi tempat hotel di Singaraja, Maps, penilaian pengguna, dan komentar dari pengunjung.
\end{abstract}

Kata kunci: Sistem Pendukung Keputusan, AHP, TOPSIS, Hotel, Waterfall.

\begin{abstract}
Decision supporting system by AHP and TOPSIS of hotel determination in Buleleng district is a developing system which is used to help visitors in determining hotel according to the criteria. Research method used in the study and development of decision supporting system of hotel determination is in accordance with the steps on SLDC method with waterfall model. As a result of the study is website application which is implemented by using sublime text 2 with PHP, HTML and Javascript programming language. The test of decision supporting system by AHP and TOPSIS of hotel determination in Buleleng district shows that the application has run well. The users response on decision supporting system of determination are in the tiptop range with an $89 \%$ percentage. Features provided in the app include hotel information in Singaraja, Maps, user ratings, and comments from visitors.
\end{abstract}

Keywords: Decision supporting system, AHP, TOPSIS, Hotel, Waterfall 


\section{PENDAHULUAN}

Perkembangan teknologi informasi telah berkembang semakin pesat dari tahun ke tahun. Hampir seluruh daerah terpencil sekarang dapat merasakan teknologi yang berkembang saat ini. Teknologi informasi digunakan untuk mengolah data, termasuk memproses, mendapatkan, menyusun, menyimpan, manipulasi data dalam berbagai cara untuk menghasilkan informasi yang berkualitas, yaitu informasi yang relevan, akurat dan tepat waktu yang digunakan untuk keperluan pribadi, bisnis, pemerintah dan merupakan informasi yang stategis untuk pengambilan keputusan [1]. Perkembangan teknologi informasi ini, berdampak besar pada berbagai bidang kehidupan masyarakat baik dari segi sosial, ekonomi, pendidikan, pembangunan, maupun pariwisata [2].

Kecamatan Buleleng merupakan pusat pemerintahan Kabupaten Buleleng. Disinilah pusat-pusat kantor daerah Kabupaten Buleleng berada. Berdasarkan letaknya, daerah Kecamatan Buleleng sangat stategis, yang berada ditengahtengah Kabupaten Buleleng sehingga mempermudah wisatawan untuk melakukan perjalanan wisata sehingga tidak memperlukan waktu yang cukup lama. Kecamatan Buleleng memiliki beberapa kekuatan daya tarik, seperti pantai pantai yang indah, kuliner, budaya yang menarik, masyarakat yang ramah, dan masih banyak yang lainnya. Daya Tarik pariwisata disekitarnya yang mudah dicapai antara lain: Air Panas Banjar, Wihara Budha, Air Terjun Gitgit, dan desa-desa sekitarnya yang sangat ideal untuk mereka yang mencintai alam / ecotourism [3].

Perpaduan keindahan alam, seni dan budaya membuat banyak wisatawan baik domestik maupun mancanegara yang datang ke Buleleng untuk keperluan karya wisata, bisnis, dan lain-lain. Dengan semakin bertambah banyaknya fasilitas dan tempat wisata yang dikunjungi, hotel merupakan salah satu tempat yang dibutuhkan sebagai fasilitas penginapan [2]. Sehingga banyak pengusaha yang memanfaatkan peluang ini dengan membangun hotel untuk pengunjung di Buleleng dengan beragam kelas hotel, harga, fasilitas, dan layanan.Wisatawan yang akan menginap di suatu hotel perlu menentukan hotel yang tepat sesuai dengan kriterianya, dengan banyaknya jumlah hotel yang tersedia sering kali pengunjung bingung untuk memilih dan mencari yang sesuai dengan kebutuhannya [4]. Wisatawan hanya memanfaatkan internet sebagai cara untuk mencari informasi tentang hotel. Selama ini pencarian menggunakan internet hanya berfokus pada kata kunci yang diberikan [5].

Sistem Pendukung Keputusan (SPK) digunakan sebagai alat bantu bagi para pengambil keputusan untuk memperluas kapabilitas para pengambil keputusan, namun tidak untuk menggantikan penilaian para pengambil keputusan [6]. Dalam sistem pendukung keputusan terdapat beberapa terdapat beberapa metode yang dapat digunakan salah satunya Analytic Hierarchy Process (AHP). Metode AHP merupakan suatu model pendukung keputusan yang dikembangkan oleh Thomas L. Saaty. Metode AHP ini dipilih karena metode ini menguraikan masalah multi faktor atau multi kriteria yang kompleks menjadi suatu hirarki. Dengan hirarki, suatu masalah yang kompleks dapat diuraikan ke dalam kelompok-kelompoknya yang kemudian diatur menjadi suatu bentuk hirarki sehingga permasalahan akan tampak lebih terstruktur dan sistematis [7]. Untuk melakukan perangkingan alternatif digunakan metode TOPSIS. Metode TOPSIS menggunakan prinsip bahwa alternatif yang terpilih harus mempunyai jarak terdekat dari solusi ideal positif dan solusi ideal negatif dari sudut pandang geometris dengan menggunakan jarak Euclidean untuk menentukan kedekatan relatif dari suatu alternatif dengan solusi optimal [8].

Sebelum penelitian ini dilakukan, sudah ada penelitian yang dilakukan oleh Hafsah pada tahun 2011 dalam judul "Sistem Pendukung Keputusan Penentuan Hotel dengan Menggunakan Metode Promethee dan AHP" adapun hasil dari penelitian ini adalah sistem mampu menampilkan pilihan-pilihan alternatif dari setiap hotel yang berada di Yogyakarta, 
setiap alternatif diurutkan berdasarkan nilai prioritas yang tertinggi sampai yang terendah. Kelebihan dari penelitian ini adalah sistem yang dikembangkan memiliki struktur hierarki yang terstruktur sehingga proses penentuan prioritas alternatif menjadi lebih mudah. Kekurangan dari penelitian ini adalah sistem ini hanya mencakup kelas bintang empat dan bintang lima sehingga ruang lingkup objek hotel masih terbatas dan perlu ditambahkan informasi mengenai rute dan saran hotel yang yang sesuai dengan selera dan kriteria pengguna [1].

Berdasarkan pemaparan tersebut peneliti tertarik untuk melakukan penelitian dengan judul "Pengembangan Sistem Pendukung Keputusan Penentuan Hotel di Kecamatan Buleleng dengan Metode Analytical Hierarchy Process (AHP) dan Technique For Other Reference By Similarity To Ideal Solution (TOPSIS)". Fitur yang akan disediakan dalam aplikasi antara lain informasi tempat hotel di Singaraja, Maps, penilaian pengguna, dan komentar dari pengunjung. Sistem pendukung keputusan ini membantu memberikan solusi dan informasi yang lengkap bagi wisatawan dalam pengambilan keputusan pemilihan hotel di Kecamatan Buleleng dengan tepat sesuai kebutuhannya.

\section{KAJIAN TEORI}

A. Sistem Pendukung Keputusan

\section{Pengertian Sistem}

Menurut Jogiyanto terdapat dua kelompok pendekatan sistem di dalam mendefinisikan sistem, yaitu pendekatan pada prosedur dan pendekatan pada komponen/elemen [9]. Pendekatan sistem pada prosedurnya mendefenisikan sistem sebagai berikut: "Suatu sistem merupakan suatu jaringan kerja dari prosedurprosedur yang saling berhubungan, berkumpul bersama - sama untuk melakukan suatu kegiatan atau tujuan tertentu". Sedangkan pendekatan sistem pada komponen atau elemennya mendefenisikan sistem sebagai berikut: "Sistem merupakan bagian-bagian elemen yang saling berinteraksi dan saling berhubungan untuk mencapai membentuk satu kesatuan".
2. Pengertian Keputusan
Menurut Kendall terdapat tiga
macam keputusan, yang biasa dibayangkan oleh masyarakat sebagai keputusan-keputusan yang sudah ada dalam suatu deretan langkah dari terstruktur ke tidak terstruktur [10].

a Keputusan Terstruktur adalah suatu keputusan yang dilakukan berulangulang secara rutin.

b Keputusan semiterstruktur adalah keputusan yang memiliki dua sifat yaitu sebagian keputusan bila ditangani oleh komputer dan yang lain tetap harus dilakukan oleh pengambil keputusan.

c Keputusan tak terstruktur adalah keputusan yang penangannya rumit karena tidak terjadi berulang-ulang atau tidak selalu terjadi.

\section{Pengertian Sistem Pendukung Keputusan \\ Konsep Sistem Pendukung}

Keputusan pertama kali dikemukakan oleh Michael S.Scott Morton pada tahun 1970 dengan istilah Management Decision Sistem [11]. Konsep tersebut ditandai dengan dibuatnya sebuah sistem komputer yang interaktif dalam mengumpulkan data dan menggunakan model untuk mendukung keputusan penyelesaian masalah-masalah yang tidak terstruktur. Secara umum SPK dapat diartikan sebagai sistem yang dimaksudkan untuk mendukung para pengambil keputusan manajerial dalam situasi keputusan semi terstruktur. SPK dimaksudkan untuk menjadi alat bantu bagi para pengambil keputusan untuk memperluas kapabilitas mereka, namun tidak untuk menggantikan penilaian mereka. Sulpan Henry Siregar menyatakan SPK ditujukan untuk keputusan-keputusan yang memerlukan penilaian atau pada keputusan-keputusan yang sama sekali tidak dapat didukung oleh algoritma [11].

4. Komponen Sistem Pendukung
Keputusan


Adapun ketiga komponen tersebut sebagai berikut [12].

a Subsistem Manajemen Basis Data (Data Base Management Subsystem) merupakan subsistem data yang terorganisasi dalam suatu basis data. Data yang merupakan suatu sistem pendukung keputusan dapat berasal dari luar maupun dalam lingkungan. Untuk keperluan SPK, diperlukan data yang relevan dengan permasalahan yang hendak dipecahkan melalui simulasi.

b Subsistem Manajemen Basis Model (Model Base Management Subsystem), salah satu keunggulan SPK adalah kemampuan untuk mengintegrasikan akses data dan model-model keputusan. Hal ini dapat dilakukan dengan menambahkan model-model keputusan ke dalam sistem informasi yang menggunakan database sebagai mekanisme integrasi dan komunikasi diantara model-model. Karakteristik ini menyatukan kekuatan pencarian dan pelaporan data dari PDE dan pengembangan disiplin manajemen.

c Subsistem Dialog merupakan bagian dari SPK yang dibangun untuk memenuhi kebutuhan representasi dan mekanisme kontrol selama proses analisa dalam SPK ditentukan dari kemampuan berinteraksi antara sistem yang terpasang dengan user. Pemakai terminal dan sistem perangkat lunak merupakan komponen - komponen yang terlibat dalam subsistem dialog yang mewujudkan komunikasi antara user dengan sistem tersebut. Komponen dialog menampilkan keluaran sistem bagi pemakai dan menerima masukkan dari pemakai ke dalam SPK.

B. ANALYTICAL HIERARCHY PROCESS (AHP)

\section{Pengertian $A H P$}

(AHP) merupakan metode pendukung pengambilan keputusan yang dikembangkan oleh Thomas L., Saaty pada tahun 1980. AHP merupakan alat pengambil keputusan yang menguraikan suatu permasalahan kompleks dalam struktur hierarki dengan banyak tingkatan yang terdiri dari tujuan, kriteria, dan alternatif. Hierarki didefinisikan sebagai suatu representasi dari sebuah permasalahan yang kompleks dalam suatu struktur multilevel dimana level pertama adalah tujuan, yang diikuti level faktor, kriteria, subkriteria, dan seterusnya ke bawah hingga level terakhir dari alternative [13]. Dengan hierarki, suatu masalah yang kompleks dapat diuraikan ke dalam kelompok-kelompoknya yang kemudian diatur menjadi suatu bentuk hierarki sehingga permasalahan akan tampak lebih terstruktur dan sistematis.

\section{Tahap-tahapan AHP}

Adapun langkah-langkah dalam metode AHP yang harus dilakukan yaitu [13]:

a. Mendefinisikan masalah dan menentukan solusi yang diinginkan.

Dalam tahap ini kita berusaha menentukan masalah yang akan kita pecahkan secara jelas, detil dan mudah dipahami. Dari masalah yang ada kita coba tentukan solusi yang mungkin cocok bagi masalah tersebut. Solusi dari masalah mungkin berjumlah lebih dari satu. Solusi tersebut nantinya kita kembangkan lebih lanjut dalam tahap berikutnya.

b. Membuat struktur hierarki yang diawali dengan tujuan utama.

Setelah menyusun tujuan utama sebagai level teratas akan disusun level hierarki yang berada di bawahnya yaitu kriteria-kriteria yang cocok untuk mempertimbangkan atau menilai alternatif yang kita berikan dan menentukan alternatif tersebut. Tiap kriteria mempunyai intensitas yang berbeda-beda. Hierarki dilanjutkan dengan subkriteria (jika mungkin diperlukan).

c. Membuat matriks perbandingan berpasangan

Matriks yang digunakan bersifat sederhana, memiliki kedudukan kuat untuk kerangka konsistensi, mendapatkan informasi lain yang mungkin dibutuhkan dengan semua perbandingan yang mungkin dan mampu menganalisis kepekaan prioritas secara keseluruhan untuk 
perubahan pertimbangan. Pendekatan dengan matriks mencerminkan aspek ganda dalam prioritas yaitu mendominasi dan didominasi. Perbandingan dilakukan berdasarkan judgment dari pengambil keputusan dengan menilai tingkat kepentingan suatu elemen dibandingkan elemen lainnya. Untuk memulai proses perbandingan berpasangan dipilih sebuah kriteria dari level paling atas hierarki misalnya $C$ dan kemudian dari level di bawahnya diambil elemen yang akan dibandingkan misalnya A1, A2, A3, A4, A5.

d. Melakukan perbandingan berpasangan sehingga diperoleh jumlah penilaian seluruhnya sebanyak $n \times[(n-1) / 2]$ buah, dengan $\mathrm{n}$ adalah banyaknya elemen yang dibandingkan.

e. Menghitung nilai eigen dan menguji konsistensinya, jika tidak konsisten maka pengambilan data diulangi.

f. Mengulangi langkah 3,4, dan 5 untuk seluruh tingkat hirarki.

g. Menghitung vektor eigen dari setiap matriks perbandingan berpasangan, yang merupakan bobot setiap elemen untuk penentuan prioritas elemenelemen pada tingkat hirarki terendah sampai mencapai tujuan.

h. Memeriksa konsistensi hirarki

Yang diukur dalam AHP adalah rasio konsistensi dengan melihat indeks konsistensi. Konsistensi yang diharapkan adalah yang mendekati sempurna agar menghasilkan keputusan yang mendekati valid. Walaupun sulit untuk mencapai yang sempurna, rasio konsistensi diharapkan kurang dari atau sama dengan $10 \%$. Berikut adalah cara menghitung rasio konsistensi.
1) Menghitung konsistensi indeks $(\mathrm{Cl})$

$$
C I=(\lambda \max -n) / n
$$

$\lambda \max$ adalah jumlah hasil kali perkalian jumlah kolom dengan eigen faktor utama dan $\mathrm{n}$ adalah jumlah kriteria.

2) Menghitung rasio konsistensi $C R$ $C R=C I / I R$

Dengan IR adalah nilai random indeks sesuai dengan ordo matriks.

3) Memeriksa konsistensi hierarki.
Jika nilainya lebih dari $10 \%$, maka penilaian data judgment harus diperbaiki, namun jika rasio konsistensi kurang atau sama dengan 0,1 , maka hasil perhitungan bisa dinyatakan benar.

\section{TECHNIQUE FOR OTHERS REFERENCE BY SIMILARITY TO IDEAL SOLUTION (TOPSIS) \\ TOPSIS adalah salah satu metode} pengambilan keputusan multikriteria yang pertama kali diperkenalkan oleh Yoon dan Hwang (1981). TOPSIS menggunakan prinsip bahwa alternatif yang terpilih harus mempunyai jarak terdekat dari solusi ideal positif dan terjauh dari solusi ideal negatif dari sudut pandang geometris dengan menggunakan jarak Euclidean untuk menentukan kedekatan relatif dari suatu alternatif dengan solusi optimal [8]:

Langkah-langkah penyelesaian masalah MADM dengan TOPSIS [14]:

1. Membuat matriks keputusan yang ternormalisasi.

2. Membuat matriks keputusan yang ternormalisasi terbobot.

3. Menentukan matriks solusi ideal positif \& matriks solusi ideal negatif.

4. Menentukan jarak antara nilai setiap alternative dengan matriks solusi ideal positif dan matriks solusi ideal negatif.

5. Menentukan nilai preferensi untuk setiap alternatif.

\section{METODELOGI}

Pengembangan aplikasi sistem pendukung keputusan penentuan hotel di Kecamatan Buleleng dengan metode AHP dan TOPSIS ini mengunakan proses SDLC (System Development Life Cycle). Model yang digunakan dalam membangun Aplikasi ini adalah Model Waterfall. Model Waterfall ini merupakan model yang di kembangkan oleh Winston Royce pada tahun 1970-an. Model waterfall merupakan model klasik yang sederhana dengan aliran sistem yang linier, masukan pada suatu tahapan merupakan keluaran dari tahapan sebelumnya. Menurut Sommerville (2003) metode waterfall adalah suatu proses pengembangan perangkat lunak berurutan, di mana kemajuan dipandang sebagai terus mengalir ke bawah (seperti air terjun) 
melewati fase-fase perencanaan, pemodelan, implementasi (konstruksi), dan pengujian. Terdapat beberapa tahapan dalam pengembangan sistem menggunakan metode waterfall, antara lain requirments definition, System design, Implementation, Integration and testing, Maintenance.

\section{A. Requirments Definition}

Tahap requirments definition merupakan tahapan yang paling awal. Tahapan ini mengumpulkan kebutuhan secara lengkap kemudian dianalisis dan didefinisikan kebutuhan yang harus dipenuhi oleh program yang akan dibangun. Pada tahap ini peneliti melakukan analisa terhadap kriteria alternatif yang diperlukan, kebutuhan fungsional, kebutuhan non fungsional, Use Case Diagram, Activity Diagram.

\section{B. System and Software Design}

Pada tahap ini peneliti melakukan perancangan sistem, konsep desain desain.

\section{Implementation and Unit Testing}

Implementasi merupakan tahapan selajutnya setelah tahap perancangan. Pada tahap implementasi, desain program diterjemahkan ke dalam kode-kode dengan menggunakan bahasa pemrograman yang sudah ditentukan.

\section{Integration and testing}

Tahap ini merupakan tahap dimana rancangan aplikasi yang telah dibuat, diimplementasikan, untuk selanjutnya diuji apakah semua komponen dari aplikasi sudah berjalan sesuai dengan fungsinya. Pengujian yang akan dilakukan meliputi blackbox testing, whitebox testing, uji kesesuaian sistem, uji media,dan uji respon pengguna.

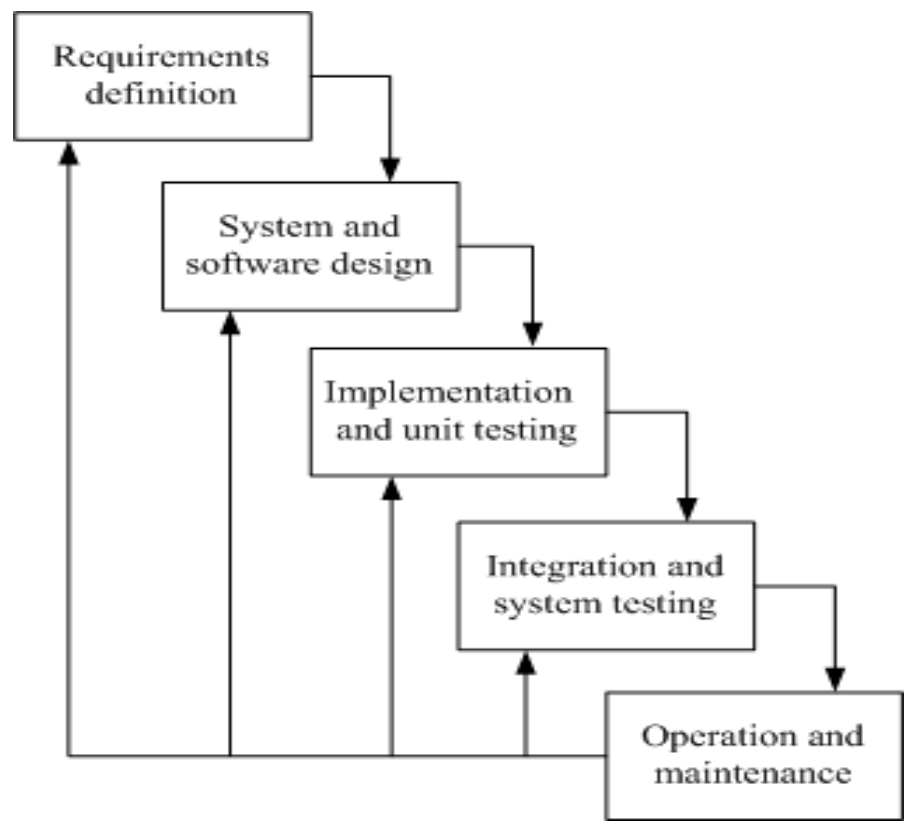

Gambar 1 Model waterfall menurut Sommerville [15].

\section{HASIL DAN PEMBAHASAN}

A. Hasil

1. Hasil tahap requirments definition

a) Kebutuhan Fungsional

Berdasarkan analisis yang dilakukan terdapat beberapa prosedur dan proses yang harus terdapat pada sistem. Adapun proses dan prosedur tersebut adalah: a. User dapat melihat data hotel beserta data rincinya yang meliputi data umum, peta, penilaian pengguna, dan komentar dari akses pengguna.

b. User dapat memberikan komentar pada setiap data hotel yang ada pada sistem. 
c. User dapat memberikan penilaian terhadap hotel tersebut sesuai dengan kriteria yang telah ditetapkan.

d. User dapat mengusulkan hotel untuk data pada system.

e. User dapat mengubah informasi akun miliknya.

f. Admin dapat memanipulasi data hotel, meliputi menambah, mengubah, menghapus dan melihat.

g. Admin dapat mengelola data komentar meliputi, menambah dan menghapus komentar.

h. Admin dapat mengelola data penilaian pengguna meliputi menambah dan mengurangi data.

i. Admin dapat mengubah username dan password untuk admin.

j. Admin dapat mengelola data pengguna dan pengelola.

k. Admin dapat mengelola data saran hotel

I. Pengelola dapat mengelola data hotel yang dikelola.

m. Pengelola dapat mengubah informasi akunnya.

b) Kebutuhan Non-Fungsional Kebutuhan non-fungsional dari Aplikasi antara lain:

a. Desain antarmuka Aplikasi dirancang sedemikian rupa agar memudahkan pengguna aplikasi untuk menggunakannya (user friendly).

b. Aplikasi dapat membantu pengguna dengan cepat menentukan hotel yang akan dipilih.

\section{c) Kriteria Alternatif}

Kriteria merupakan acuan yang digunakan dalam menentukan suatu keputusan dalam sebuah SPK. Pada penelitian ini, kriteria yang digunakan didapat dari hasil studi pustaka beberapa penelitian yang sejenis. Berdasarkan hasil analisis dari beberapa sumber kajian tersebut maka penulis menetapkan kriteria yang digunakan dalam penelitian ini antara lain harga, kelas, lokasi, fasilitas, rating, dan layanan dengan subkriteria kebersihan, menarik, kenyamanan, dan keamanan. d) Contoh Perhitungan Manual dengan Metode AHP dan TOPSIS

Seorang pengunjung berencana untuk menginap di salah satu dari tiga hotel di Kecamatan Buleleng yang direkomendasikan untuknya. Pengunjung tersebut tidak mengetahui hotel mana yang benar-benar sesuai dengan seleranya. Berikut solusi yang dapat ditawarkan dengan menggunakan metode AHP dan TOPSIS. Diketahui data dari alternatif yang ditawarkan sebagai berikut:

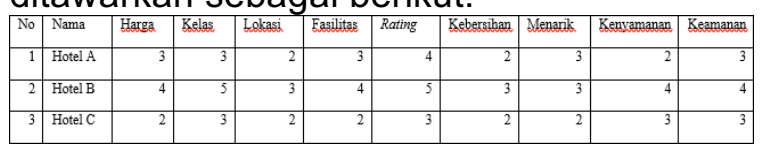

Langkah pertama yang dilakukan adalah mencari nilai bobot per kriteria dengan menggunakan metode AHP. Data perbandingan kepentingan yang sudah disusun kedalam matriks perbandingan berpasangan.

\begin{tabular}{|l|l|l|l|l|l|l|}
\hline Kriteria & Harga & Kelas & Lokasi. & Easilitas & Rating & Lavanan \\
\hline Harga & $1 / 1$ & $3 / 1$ & $4 / 1$ & $4 / 1$ & $5 / 1$ & $3 / 1$ \\
\hline Kelas & $1 / 3$ & $1 / 1$ & $2 / 1$ & $2 / 1$ & $3 / 1$ & $1 / 1$ \\
\hline Lokbasi & $1 / 4$ & $1 / 2$ & $1 / 1$ & $1 / 1$ & $2 / 1$ & $1 / 2$ \\
\hline Easilitas & $1 / 4$ & $1 / 2$ & $1 / 1$ & $1 / 1$ & $2 / 1$ & $1 / 2$ \\
\hline Rating & $1 / 5$ & $1 / 3$ & $1 / 2$ & $1 / 2$ & $1 / 1$ & $1 / 3$ \\
\hline Lavanan & $1 / 3$ & $1 / 1$ & $2 / 1$ & $2 / 1$ & $3 / 1$ & $1 / 1$ \\
\hline
\end{tabular}

Setelah menyusun nilai perbandingan kepentingan kriteria, tahapan selanjutnya adalah mencari nilai eigen matriks dengan cara mengkuadratkan matriks. Lakukan iterasi pada tahapan ini sehingga selisih dari satu iterasi dan iterasi sebelumnya sangat kecil. Pada kasus ini iterasi dilakukan sampai empat kali. Selisih yang didapat sudah sangat kecil yakni kurang dari $1 \times 10^{-5}$.

\begin{tabular}{|l|l|l|r|l|}
\hline iterasi 3 & iterasi 4 & selisih & Tetapan & valid \\
\hline 0.243813001 & 0.243813837 & $8.36201 \mathrm{E}-07$ & 0.00001 & Yes \\
\hline 0.066412215 & 0.066411314 & $9.0034 \mathrm{E}-07$ & 0.00001 & Yes \\
\hline 0.129246127 & 0.129244782 & $1.3444 \mathrm{E}-06$ & 0.00001 & Yes \\
\hline 0.560528658 & 0.560530066 & $1.40854 \mathrm{E}-06$ & 0.00001 & Yes \\
\hline
\end{tabular}

Selanjutnya, menghitung nilai konsistensi indeks dari matriks berpasangan dengan rumus: $\mathrm{Cl}=((\lambda$ maxn)) / $\mathrm{n}$ dan didapatkan hasil 0.00990964 . Setelah didapat nilai konsistensi indeks selanjutnya mencari konsistensi rasio dengan rumus: $\mathrm{CR}=\mathrm{Cl} / \mathrm{IR}$ dan didaptkan hasil 0.007991645 . Karena 0.007991645 
lebih kecil dari 0.1 maka perbandingan kepentingan dapat dikatakan konsisten.

Selanjutnya mencari nilai mencari nilai eigen pada subkriteria Layanan dengan menggunakan metode AHP dengan melakukan tahapan yang sama seperti sebelumnya.

\begin{tabular}{|l|l|l|l|l|}
\hline Sublriteria & Kebersichan & Menarik & Kenvamanan & Keamanan \\
\hline Kebersihan & $1 / 1$ & $4 / 1$ & $3 / 1$ & $1 / 4$ \\
\hline Menarik & $1 / 4$ & $1 / 1$ & $1 / 3$ & $1 / 5$ \\
\hline Kenvamanan & $1 / 3$ & $3 / 1$ & $1 / 1$ & $1 / 4$ \\
\hline Keamanan & $4 / 1$ & $5 / 1$ & $4 / 1$ & $1 / 1$ \\
\hline
\end{tabular}

Sehingga didapatkan semua nilai bobot kriteria sebagai berikut:

\begin{tabular}{|l|r|}
\hline Kriteria & \multicolumn{1}{|l|}{ Bobot } \\
\hline Harga & 0.410251442 \\
\hline Kelas & 0.170461329 \\
\hline Lobasi & 0.095623801 \\
\hline Fasilitas & 0.095623801 \\
\hline Rating & 0.057578299 \\
\hline Laxanan & \\
\hline - Kebersihan & 0.041560831 \\
\hline - Menarik & 0.011320561 \\
\hline - Kenyamanan & 0.022031237 \\
\hline - Keamanan & 0.0955487 \\
\hline
\end{tabular}

Selanjutnya menggunakan metode TOPSIS untuk tahap perangkingan. Membuat matriks keputusan dari data yang ada. Normalisasi matriks keputusan yang sudah dibentuk. Setelah melakukan normalisasi, membuat normalisasi terbobot dengan cara data normalisasi dikali dengan bobot kriteria.

\begin{tabular}{|l|l|l|l|l|l|l|l|l|l|}
\hline Nama & Harga & Kelas & Lokasi & Fasiltas & Rating & Kebershan & Menark & Kenvamanan & Keamanan \\
\hline Hotel A & 0.228545 & 0.077985 & 0.046384 & 0.053271 & 0.032571 & 0.020160 & 0.007241 & 0.008182 & 0.049159 \\
\hline Hotel B & 0.304727 & 0.129976 & 0.069577 & 0.071028 & 0.040714 & 0.030240 & 0.007241 & 0.016364 & 0.065546 \\
\hline Hotel C & 0.152364 & 0.077985 & 0.046384 & 0.035514 & 0.024428 & 0.020160 & 0.004827 & 0.012273 & 0.049159 \\
\hline
\end{tabular}

Selanjutnya mencari nilai Max dan Min dari normalisasi terbobot. Setelah mendapatkan nilai Max dan Min, selanjutnya mencari solusi ideal positif dan solusi ideal negatif. Jika kriteria bersifat benefit (makin besar makin baik) maka $\mathrm{Y}+$ $=$ MAX dan $Y-=$ MIN, jika kriteria bersifat cost (makin kecil makin baik) maka $\mathrm{Y}+=$ MIN dan Y- = MAX. Dalam permasalah ini, yang bersifat benefit terdiri dari kelas, fasilitas, keamanan, kebersihan, menarik, dan kenyamanan. Sedangkan yang bersifat cost yaitu harga dan lokasi.

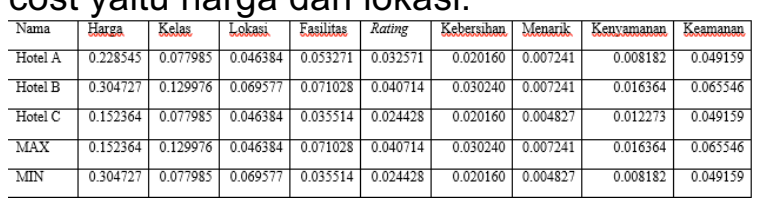

Selanjutnya mencari jarak solusi ideal positif dan solusi ideal negatif. Dan hasil akhirnya sebagai berikut:

\begin{tabular}{|l|r|}
\hline Nama & Prioritas \\
\hline Hotel A & 0.459301372 \\
\hline Hotel B & 0.307248226 \\
\hline Hotel C & 0.693975247 \\
\hline
\end{tabular}

Hotel C memperoleh nilai prioritas yang paling tinggi.

e) Use Case Diagram

Use Case Diagram menggambarkan fungsionalitas yang diharapkan dari sebuah sistem. Menggambarkan kebutuhan sistem dari sudut pandang pengguna (user), memfokuskan pada proses komputerisasi (automated process). Berikut ini adalaj use case diagram dari sistem pendukung keputusan penentuan hotel di Kecamatan Buleleng. 


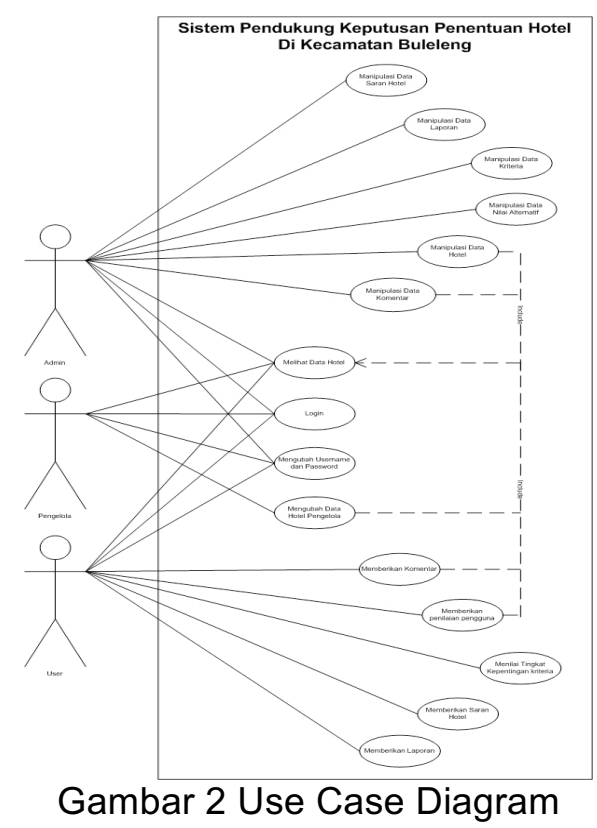

2. Hasil tahap system and software Design

a) Arsitektur sistem

Sistem Pendukung Keputusan ini dapat digunakan oleh tiga jenis pengguna yakni admin, pengelola, dan user. Admin merupakan jenis pengguna yang bertugas mengelola data-data penting yang dapat mempengaruhi kinerja sistem. Pengelola adalah merupakan jenis pengguna yang bertugas mengelola data-data hotel. User adalah pengguna yang memiliki akses untuk menggunakan semua fitur yang disediakan sistem. Ketiga jenis pengguna tersebut dihubungkan dengan internet ke database untuk dapat mengakses dan mengelola data yang ada pada sistem.

b) RAT (Rancangan Antar Tabel)

Rancangan Antar Tabel (RAT) merupakan hubungan yang yang terjadi pada suatu tabel dengan tabel lainnya, yang berfungsi untuk mengatur operasi suatu database. Relasi antar tabel dari Sistem Penunjang Keputusan Penentuan Hotel di Kecamatan Buleleng sebagai berikut:

c) Rancangan Antar Muka Rancangan antarmuka merupakan gambaran dari rencana antarmuka yang akan diimplementasikan dalam Sistem Penunjang Keputusan Penentuan Hotel Di Kecamatan Buleleng, fungsi web disini sebagai fasilitas untuk berinteraksi antara pengguna dengan sistem.

Berikut ini merupakan beberapa rancangan antarmuka Sistem Penunjang Keputusan Penentuan Hotel Di Kecamatan Buleleng

1. Rancangan Antarmuka Admin Data Hotel

\section{Gambar 3.Rancangan Antarmuka Admin Data Hotel}

Rancangan antarmuka admin data hotel yang akan menampilkan data hotel. Admin dapat melakukan manipulasi data hotel seperti mengubah, menghapus, menambahkan.

2. Rancangan Antarmuka Penentuan Hotel 
Gambar 4. Rancangan Antarmuka Penentuan Hotel

Rancangan antarmuka penentuan hotel akan menampilkan form tingkat perbandingan kepentingan dari masingmasing kriteria.

3. Hasil Tahap Implementation and Unit Testing

a) Lingkungan Implementasi Aplikasi dikembangkan menggunakan beberapa perangkat lunak sebagai berikut.

1. Sistem Operasi Windows 10

2. Sublime Text 2

3. XAMPP

4. Corel Draw X7

Aplikasi dikembangkan menggunakan beberapa perangkat keras sebagai berikut.

1. Monitor 14 inchi dengan resolusi 1366 $\times 768$

2. Memori 8 GB RAM dan harddisk 500 GB

3. Processor Intel $\circledast$ Core $^{\mathrm{TM}} \quad i 5-3317 \mathrm{U}$ @1,70 GHz

b) Implementasi Layar Antarmuka Implementasi layar antarmuka perangkat lunak dilakukan berdasarkan rancangan antarmuka yang telah dilakukan.

a. Implementasi Detail DataHotel User

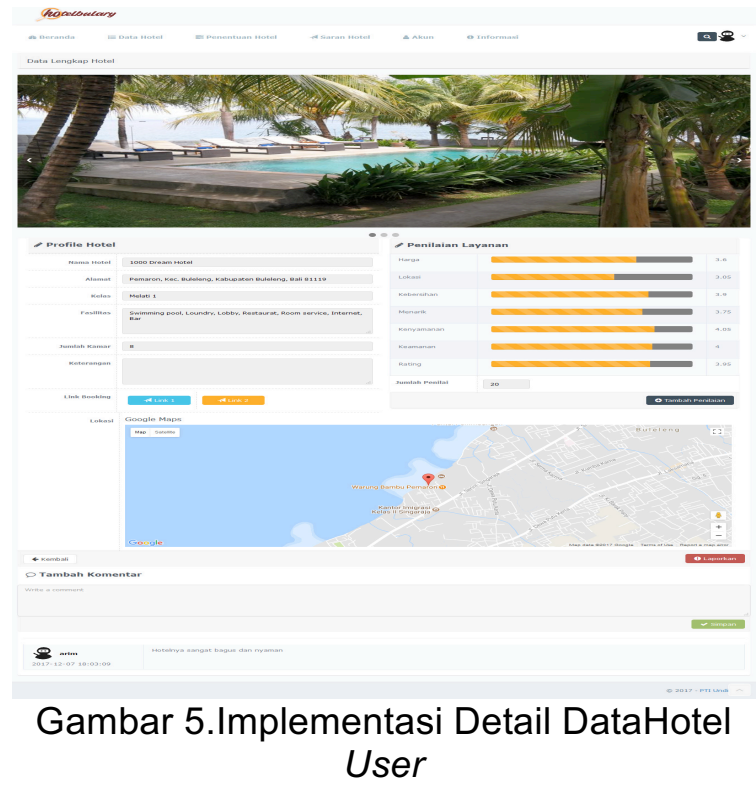

Antarmuka perangkat lunak user detail data hotel merupakan halaman yang berfungsi menampilkan keseluruhan informasi tentang hotel. Pada antarmuka tersebut akan ditampilkan informasi lengkap, peta, data penilaian pengguna dan komentar pengguna.

b. Implementasi Tambah Data Hotel Admin Antarmuka perangkat lunak admin tambah data hotel merupakan halaman yang berfungsi untuk menambahkan hotel baru kedalam sistem oleh admin.

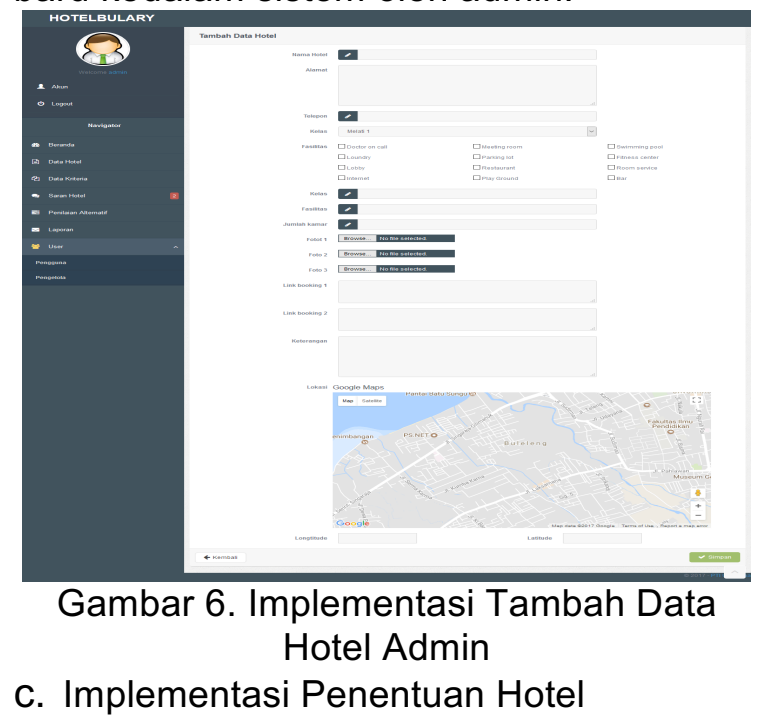




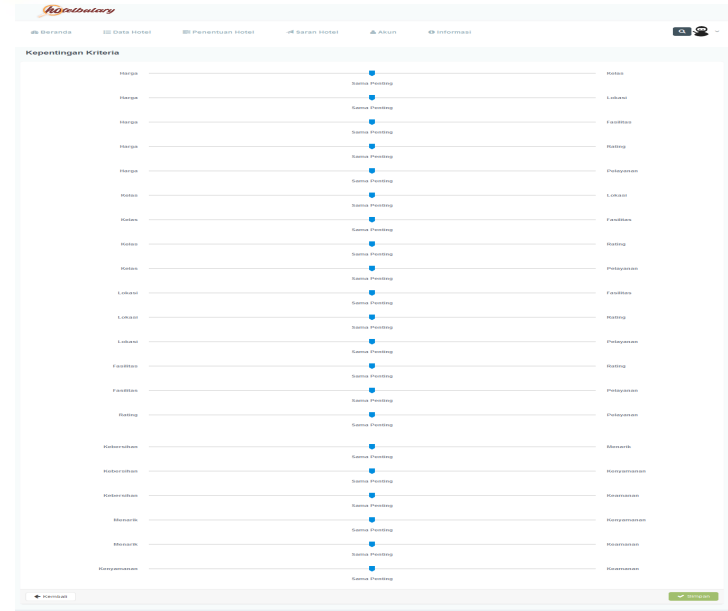

Gambar 7. Implementasi Penentuan Hotel

Antarmuka perangkat lunak penentuan hotel merupakan halaman yang berfungsi menampilkan antarmuka untuk membandingkan tingkat kepentingan kriteria satu dengan yang lain apabila tingkat perbandingan konsisten maka akan ditampilkan rekomendasi tempat hotel sesuai dengan hasil perhitungan.

\section{Hasil Tahap Integration and Testing}

Pengujian perangkat lunak dilakukan melalui beberapa pengujian, yaitu black box testing, white box testing, uji ahli media, uji respon pengguna dan uji kesesuaian sistem

Pengujian black box dilaksanakan oleh dua orang penguji. Pengujian dilakukan sesuai dengan item uji yang telah dirancang. Dari 59 tahapan pengetesan didapatkan hasil sebanyak $100 \%$ sesuai. Selanjutnya pada pengujian struktural (white box testing), hasilnya menyimpulkan bahwa proses kerja perangkat lunak secara internal bekerja dengan baik sesuai dengan spesifikasi yang telah ditetapkan. Source code program bekerja dengan baik dan benar sesuai dengan fungsinya.

Pengujian ahli media yang telah dilakukan oleh 2 orang ahli, presentase hasil uji ahli media yaitu $85 \%$ berarti hasil respon dalam rentangan Sangat Baik.

Pengujian kesesuaian sistem meliputi pengujian kesesuaian hasil dengan membandingkan hasil perangkingan dengan metode AHP dan TOPSIS secara manual dengan hasil yang diperoleh dari sistem. Adapun hasil dari pengujian Sistem
Pendukung Keputusan Penentuan Hotel di Kecamatan Buleleng dengan metode AHP dan TOPSIS memiliki tingkat kesesuaian sistem sebesar $100 \%$.

Pengujian respon pengguna, pengujian melibatkan 30 orang pengguna secara acak. Berdasarkan hasil perhitungan respon pengguna secara umum, dapat disimpulkan bahwa sistem pendukung keputusan penentuan hotel di Kecamatan Buleleng dengan metode AHP dan TOPSIS sangat sesuai untuk digunakan sebagai rujukan dalam menentukan tempat hotel yang sesuai dengan nilai persentasi sebesar $89 \%$ berarti hasil respon dalam rentangan Sangat Baik.

\section{B. Pembahasan}

Sesuai dengan paparan hasil pengembangan Sistem Pendukung Keputusan Penentuan Hotel di Kecamatan Buleleng dengan metode AHP dan TOPSIS maka berikut ini diuraikan pembahasan. Pembahasan difokuskan pada implementasi dan hasil pengujian serta disampaikan kendala - kendala terhadap produk pengembangan Sistem Pendukung Keputusan Penentuan Hotel di Kecamatan Buleleng dengan metode AHP dan TOPSIS.

Berdasarkan hasil pengembangan menggunakan metode AHP dan TOPSIS telah memadai untuk digunakan dalam proses pemilihan, dalam penelitian ini pemilihan hotel di Kecamatan Buleleng. Pada kasus ini penentuan bobot kriteria dilakukan dengan metode AHP dan proses perankingan alternatif dengan metode TOPSIS. Pada penentuan bobot kriteria, penggunaan metode AHP sangat efektif karena kriteria yang digunakan pada sistem ini bersifat kualitatif dan kuantitatif. Dan pada proses perangkingan, penggunaan metode TOPSIS menggunakan prinsip bahwa alternatif yang terpilih harus mempunyai jarak terdekat dari solusi ideal positif dan terjauh dari solusi ideal negatif dari sudut pandang geometris dengan menggunakan jarak Euclidean untuk menentukan kedekatan relatif dari suatu alternatif dengan solusi optimal.

Pengembangan Sistem Pendukung Keputusan Penentuan Hotel di Kecamatan 
Buleleng dengan metode AHP dan TOPSIS yang dikembangkan sesuai dengan Metode AHP dan TOPSIS ini mengunakan proses SDLC (System Development Life Cycle). Model yang digunakan dalam membangun Aplikasi ini adalah Model Waterfall. Terdapat beberapa tahapan dalam pengembangan sistem menggunakan metode waterfall, antara lain requirments definition, system design, Implementation and unit testing, Integration and testing.

Berdasarkan hasil pengujian black box dan white box dilakukan didapatkan hasil bahwa aplikasi sudah sesuai dengan rancangan dan kebutuhan yang telah disusun. Pada pengujian ahli media pada Sistem Pendukung Keputusan Penentuan Hotel di Kecamatan Buleleng dengan metode AHP dan TOPSIS dengan angket menunjukan bahwa sistem ini memperoleh hasil uji media sebesar $85 \%$. Hal ini jika dikonversi berdasarkan tabel konversi berarti sangat baik. Adapun masukan setelah melakukan pengujian yaitu hasil perhitungan dirasa tidak perlu ditampilkan untuk user umum, cukup ditampilkan prioritas yang tertinggi hingga terendah, warna tampilan mungkin bisa divariasikan, perlu dan menambahkan link untuk booking hotel.

Berdasarkan hasil respon pengguna yang dilakukan dengan cara menyebarkan angket kepada 30 orang. Dimana setelah menggunakan Sistem Pendukung Keputusan Penentuan Hotel di Kecamatan Buleleng dengan metode AHP dan TOPSIS dengan hasil angket menunjukkan kualifikasi sangat baik dengan nilai persentase $89 \%$. Adapun tanggapan dari pengguna yaitu sistem dapat membantu saya dalam memilih hotel di sekitaran Kecamatan Buleleng. Selanjutnya pada pengujian kesesuaian sistem menunjukan bahwa Aplikasi memiliki tingkat kesesuaian sistem yang sangat sesuai dengan persentase keseluruhan penilaian yaitu $100 \%$.

Namun tidak terlepas dari beberapa hal yang masih menjadi kekurangan dari aplikasi Sistem Pendukung Keputusan Penentuan Hotel di Kecamatan Buleleng dengan metode AHP dan TOPSIS ini, diantaranya jumlah iterasi yang digunakan pada saat mencari nilai eigen matriks pada perhitungan terbatas sampai 10 iterasi, sehingga input yang dimasukan pengguna akan dikatakan tidak konsisten dan pengguna disuruh untuk menginputkan ulang. Untuk itu penulis mengharapkan jika kedepannya sistem ini dikembangkan perlu memerhatikan kelemahan sistem saat ini sebagai bahan pertimbangan untuk melakukan pengembangan sistem berikutnya.

\section{SIMPULAN}

Berdasarkan penelitian sistem "Pengembangan Sistem Pendukung Keputusan Penentuan Hotel di Kecamatan Buleleng dengan metode AHP dan TOPSIS" yang telah dilakukan, maka diperoleh kesimpulan sebagai berikut.

1. Sistem Pendukung Keputusan Penentuan Hotel di Kecamatan Buleleng dengan metode AHP dan TOPSIS ini, berdasarkan hasil pengembangan menggunakan metode AHP dan TOPSIS telah memadai untuk digunakan dalam proses pemilihan hotel, pada kasus ini penentuan bobot kriteria dilakukan dengan metode AHP dan proses perankingan alternatif dengan metode TOPSIS. Pada penentuan bobot kriteria, penggunaan metode AHP sangat efektif karena kriteria yang digunakan pada sistem ini bersifat kualitatif dan kuantitatif. Dan pada proses perangkingan, penggunaan metode TOPSIS menggunakan prinsip bahwa alternatif yang terpilih harus mempunyai jarak terdekat dari solusi ideal positif dan terjauh dari solusi ideal negatif dari sudut pandang geometris dengan menggunakan jarak Euclidean untuk menentukan kedekatan relatif dari suatu alternatif dengan solusi optimal. Dan dalam pengembangan sistem ini mengunakan proses SDLC (System Development Life Cycle). Model yang digunakan dalam membangun Aplikasi ini adalah Model Waterfall. Sistem ini dirancang dengan menggunakan usecase diagram dan activity diagram. Pengimplementasian Sistem Pendukung Keputusan Penentuan Hotel di Kecamatan Buleleng dengan metode 
AHP dan TOPSIS menggunakan Sublime Text 2 dengan Bahasa pemrograman PHP, HTML dan Javascript.

2. Respon pengguna terhadap aplikasi Sistem Pendukung Keputusan Penentuan Hotel di Kecamatan Buleleng dengan metode AHP dan TOPSIS dinyatakan sangat baik dengan persentase $89 \%$.

Berdasarkan hasil penelitian, pengembangan, dan kesimpulan yang telah dipaparkan sebelumnya, terdapat beberapa saran untuk penelitian selanjutnya antara lain: (1) Pengembangan selanjutnya agar penentuan jumlah iterasi yang digunakan dalam pencarian nilai eigen pada perhitungan AHP lebih diperhitungkan agar user lebih leluasa dalam melakukan perbandingan kriteria. (2) Dalam memecahkan masalah multikriteria metode AHP dan TOPSIS bukan satu-satunya penggabungan metode pengambilan keputusan yang dapat digunakan, alangkah lebih baik dicoba untuk menggunakan metode penggabungan yang lain untuk mengdukung keputusan yang lebih efektif

\section{REFERENSI}

[1] Hafsah, Kodong, F. R., \& Julian, A. (2011). Sistem Pendukung Keputusan Penentuan Hotel Dengan Menggunakan Metode Promitee dan AHP. Seminar Nasional Informatika (pp. 43-50). Yogyakarta: UPN Veteran.

[2] Hartini, D. C., Ruskan, E. L., \& Ibrahim, A. (2013). Sistem Pendukung Keputusan Pemilihan Hotel Di Kota Palembang Dengan Metode Simple Additive Weighting (SAW). Jurnal Sistem Informasi (JSI), VOL. 5, NO. 1, 546-565.

[3] Dinas Kebudayaan dan Pariwisata Kabupaten Buleleng. (2015). Direktori Hotel, Pondok Wisata, Rumah Makan, Hotel dan Bar Kabupaten Buleleng Tahun 2015. Singaraja: Dinas Kebudayaan dan Pariwisata Kabupaten Buleleng.

[4] Deviyanti, G. (2012). Pembangunan Sistem Pendukung Keputusan Pemilihan Hotel Di Yogyakarta dengan
Metode Weighted Product Berbasis Web. Yogyakarta: Universitas Atma Jaya Yogyakarta, Fakultas Teknologi Industri, Teknik Informatika.

[5] Budi, R. S., Indriyati, \& Endah, S. N. (2012). Sistem Pendukung Keputusan Penentuan Lokasi Kuliner Di Semarang dengan Metode Simple Additive Weighting. JOINT, VOL 13, NO 2, 9-16.

[6] Efraim Turban, J. E. (2001). Decision Support Systems And Intelligent Systems. New Jersey: Prentice Hall.Setiawan, S. 1993. Artificial Intelligence. Yogyakarta: Andi Offset.

[7] Gunawan, A. (2014). Sistem Pendukung Keputusan Untuk Perekrutan Karyawan Dengan Menggunakan Metode AHP (Analytical Hierarchy Process) Study Kasus Pada PT.Valprisma Jaya Abadi. UDiNus Repository.

[8] Ridaini. (2014). Sistem Pendukung Keputusan Pemilihan Lokasi Objek Wisata Di Aceh Tengah Menggunakan Metode TOPSIS. Informasi dan Teknologi IImiah (INTI), Volume : IV, Nomor : 3 , 33-40.

[9] Jogiyanto, H. M. (1990). Analisis Dan Desain Sistem Informasi Pendekatan Terstruktur. Yogyakarta: Andi.

[10] Santoso, P. B. (2012, May 10). Keputusan (Decision). Retrieved from Budi Akademika: http://pbsabn.lecture.ub.ac.id/2012/05/k eputusan-decision/

[11] Siregar, S. H. (2013). Sistem Penunjang Keputusan Untuk Menentukan Pelanggan Terbaik Menggunakan Metode Fuzzy Mamdani (Studi Kasus : PT. Gita Snack Cabang Medan). Pelita Informatika Budi Darma, Volume : IV, Nomor: 2, 101-105.

[12] Eniyati, S. (2011). Perancangan Sistem Pendukung Pengambilan Keputusan untuk Penerimaan Beasiswa dengan Metode SAW (Simple Additive Weighting). Jurnal Teknologi Informasi DINAMIK, Volume 16, No 2, 171-176.

[13] Fitriyani. (2012). Penerapan AHP Sebagai Model Sistem Pendukung Keputusan Pemilihan Rumah Bersalin Contoh Kasus Kota Pangkalpinang. 
JSM STMIK Mikroskil, VOL 13, NO 2,103-111.

[14] Perdana, N. G., \& Widodo, T. (2013). Sistem Pendukung Keputusan Pemberian Beasiswa Kepada Peserta Didik Baru Menggunakan Metode TOPSIS. Seminar Nasional Teknologi Informasi \& Komunikasi Terapan 2013
(SEMANTIK 2013) (pp. 265-272). Semarang: UDiNus Repository.

[15] Cristal, Linda Yeti Surya. (2017). Sistem Informasi Pemilihan Calon Ketua Osis Di Sma Pawyatan Daha, Vol. 01 No. 10 Tahun 2017. 